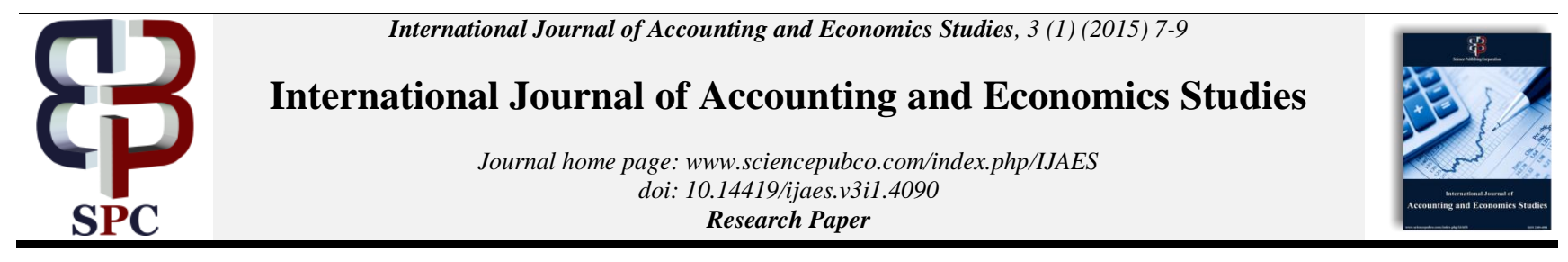

\title{
Full development of the theory of accounting and auditing
}

\author{
Shaban Mohammadi \\ Department of Accounting, Quchan Branch,Hakim Nezami University, Quchan, Iran \\ *Corresponding author E-mail:shaban1362@gmail.com
}

\begin{abstract}
Lending and public funds for political purposes, taxation, etc., require reports on new and authentic. Increase the number of uses and users of financial reports, information and capital and money market boom, accounting and auditing the objective of meeting the needs of a limited number of owners of capital to meet the needs of the community, has been upgraded. The audit will validate the information contained in the financial statements that are prepared by accountants. Audit process of accountability, and accountability requires the establishment of a social welfare system. With such interpretations role in auditing and accounting features are outstanding (Derby, 1388). To improve the reporting procedure, it is essential that the performance, resource utilization and costs and income related record. Evidence must be documented to prove liability is fully done. After thorough research and a comprehensive learning and accountability, the proposed system must be responsive to environmental, structural responsive, honest behavior and control systems have responsibility (Qu, 2006).
\end{abstract}

Keywords: Accountability; Auditing; International Accounting; Management; Responsibility.

\section{Introduction}

Answer: The major driver for the development of accounting and auditing important issue in accounting and auditing and accountability from the beginning, has attracted the attention of researchers in this field. In recent decades, the theory of accountability for the results of social psychology, organizational theory and sociological theory to attract and eventually expanded their research horizons. Response theory for the first time in China is defined as: "The answer to communicate with the agency 1 is built with stimulants such as determining the fees, appointment and appropriate choices begin. When it was established, the selected individual responsibility to act in good faith in accordance with the principles of the best and most economical way to take responsibility. It is the responsibility of the "accountability" arises. Once the agent has done his duty, should report to your boss. Contact the agency when the President agrees ends. " They must be economical, efficient and precise criteria for the use and conservation of resources and make the necessary accounting system and internal control system and report actual results and revenue management, choice (Chen et al., 2012). So, the answer is not a fixed and static concept, but the concept is dynamic and changing (Chen et al., 2012). Accountability based on the "Theory of Trust" established by the resources that have been developed since the 1950s. From 1970 to 1980 , the stakeholder theory 2 , analysis of economic operation of the separation of ownership from management and management focus on future improvements, the answer was. Storage and disposal of assets, government, employees, consumers, social and moral welfare, biological balance and control the population, is part of the concept of representation. Even within the agency also extend the concepts covered. The growth pattern of the way for a future state accountability chain and cyclic cross has become a model. Organizations and social progress, with representation of more complex relationships. Already meet minimum reporting obligations, asset preservation, compliance regulations, economy, efficiency, competence and social responsibility plays (Cai \& Chen, 2006). The contents of the response can be divided into two categories: financial responsibility and liability management. The first requires that the agent with the best safety and integrity of asset management activities and ensure the relevant requirements of the law, moral, socio- technical IT needs. The latter only requires that the legal representative of the business, but also to act as an effective means to suit the principles of economy, efficiency, effectiveness and accountability in the management, use (Chen et al., 2012).Meet certain connection with accounting and auditing. Proxy (Pearks) to meet four basic elements introduced, recording of accounting, auditing, accounting, and accounting information display and management of crisis situations. The error (Chen et al., 2012). Sai (Cai, 2000) believes that accountability is the soul of modern accounting and auditing. Wang (Wang, 2002) believes that "Accountability is the essence of modern accounting and auditing and accountability perspective, accounting and audit provides a systematic way." Ayksyav inquiry (Xiao \& Cao, 2008) determined that Finance accounting and auditing accountability chariots are leading. Wei (Wu, 1996) believes that accountability extract accounting and accounting purpose is to introduce and provide accountability. Historically, the emergence and development of a step by step account of the origin and development of the theory of 3 comes accountability. Almost all the main processes of accounting theory on the "centrality of the issue of accountability," insist. Accountability is an important source of theory and basic accounting theory, accounting theory is established and developed. Yang notes that the foundation of the audit, audit-based accountability. If there is no accountability, audit also came into existence. When auditing is understood that the answer is understood. Audit not only because accountability is created, it is associated with the development. Qin (Qin, 1999) believes that the financial responsibility of a general economic responsibility audit 
states that, due to take place. With the new government audits not only meet the general economy started, but with the growth develop. The initial view of audit, economic impact and show responsibility. "Wang believes that accountability is not only a dynamic problem, but some thought that the emergence and development of audit controls. Accounting bridges of trust and the trustee of the principle of representation and show that the Financial Accounting Foundation is to identify measure and report the results of the full process of accountability. Chen believes that accountability as well as the gradual development of the agency relationship deepens and "accountability driven by the formation of the audit." Chen and colleagues (Chen et al., 2012) argue that accounting is to recognize and show responsibility. Financial accounting, financial accountability displays while accounting management, management accountability portrays. Based on the accounting audit is to review and show accountability. Financial accounting is the impact of financial accounting, managerial accounting, while the impact of management accounting. The classic discussion above shows that the answer is no, and the development of new accounting and auditing. Genesis account, infrastructure and the development of accounting and auditing, and thus stimulating demand and lead to the development of modern accounting and auditing them

\section{The development of accounting}

The principle of representation, management expects economic responsibility Bhshkly run honestly and completely. The delegates are expected not only to preserve the value of assets, but also add value to it. Trustees to customer needs with a sincere desire to implement the responsibility to trust him to show his win. Requirements and incentives of the agent, it creates accounting requirements that reflect the application of the accounting and responsibility for one's trust is a measure of responsibility for the application. In society, the government is responsible for public responsibility to show that the government is in need of financial accounting (Chen et al., 2012). Many investigators with international accounting, the research on the relationship between accounting and its environment dedicated. Accounting literature indicates that when the business environment changes, changes in demand for financial information provided by the accounting system, resulting in the development of accounting. Blkvyy states that accounting does not develop in a vacuum, but rather suggests that developing a particular environment. Above-mentioned accounting systems and procedures for reporting and explains why the disclosure is different from one country to another. Accounting studies that focused on the accounting and its environment, the reporting and disclosure procedures and accounting practice to measure the development of accounting used (trust and Mohammadi, 1384). From the 1950s to increase the number of firms and the intensification of competition between them, management accounting practices flourished. As the creation of new forms of corporate organization, operating rules and the right of ownership of property as two separate, three final property law, legal and operational rules are divided. Moreover, the managers of the operating profit. By extending the principle of representation, accountability, including financial responsibility in which shareholders will monitor the performance of managers (foreign financial accountability) and meet the general manager of the lead managers (internal management accountability). Multilevel internal accountability comes from the fact that external accountability within organizations to develop. Speech recognition and greater financial responsibility related to financial accounting and managerial accountability for the development of management accounting is the recognition and expression. What is the mechanism of accountability and accounting, management accounting and auditing do basic communication through methods that aim to meet, plan and budget, control, and separation is introduced. In the public sector, fiscal accountability, responsibility for the integrity of public resources to the government for financial accounting controls, detect and display (Chen et al., 2012). Moreover, in 1960 the state ad- ministration had made great progress in the field of accounting. Western countries have recently developed an advanced technology that a full report on the state of management accounting provides. In fact, the main responsibilities of the integrity of public resources are introduced and display (Zhang, 2009). For the development of accounting theory, having mastered the basics of proper accounting and analysis, their characteristics are fundamental. Also, developing techniques for the detection and measurement of items in the financial reporting process, increase employment and improve the registration and management sharing. Study of accounting theory is important not only for researchers and students, but also for those who are also professional activities related to accounting matters. The reason this matters is that the accounting policies carefully based on accounting theory (Filho \& Bruni, 2011). The purpose of accounting theory, accounting procedures is described and predicted (Watts \& Zimmerman, 1986).

\subsection{Future accounting accounting comprehensive core value chain}

Corporate management, process management experienced in the past in which the chaotic state moved towards operational management. Currently, companies are moving from operational management to integrated management and can predict the functional units and broader, deeper and more important is integrity. Consequently, the existence of deep and developed, has led management in the 21 st century will be more closely integrated management approach. In fact, the desire to integrate their management organizations recently. No financial accounting and management accounting to comply with environmental changes are in trouble. Enterprise value is reflected in the numerous flaws and weaknesses in financial accounting, management accounting practices of remote and irregular and interaction is being deleted. Expanding the scope of interest of shareholders, the concept of time and space to meet the increasing gradually. Financial accounting and management accounting have been integrated in the long term (Chen et al., 2012). Thus accounting management tool becomes the core of their value-adding activities are valuable management (Chen, 2002). Young, the accounting value chain created and this species has been introduced, "Accounting for value chain management is an activity that seeks to track, monitor and evaluate the added value chain provided by the strategic approach" he said. From the above definition, comprehensive accounting, including parts of the value chain accounting and management accounting and financial accounting integration with the will (Yan, 2004). In the twentieth century, the traditional financial audit Audit Audit of modern management was developed. Wang believes that the audit of the management of the development of accountability is achieved in two steps. Firstly, change management, and secondly to meet financial accountability, audit analysis, respond to audits based on responses from further development. Financial accounting, financial accountability confirms and reaffirms the reliability of financial statements is representative. Approved taken to mean that the financial statements are reliable or not and do not specify the amount satisfactory to the agent. Management Audit Management Accounting In addition, on a strategic level, focusing on control and performance (Wang, 2004). Chen believes new issues such as human resources, audit, performance audit, environmental audit and audit-related strategic management is management accounting (Chen, 2003). But at the same time as the financial audit and audit management considered ( $\mathrm{Li}, 2005)$. Liu (Liu, 2006) believes that the public sector can meet government regulations for the development of state and government performance audit of current and historical aspects, was studied. It is also clear that the development of management accountability, the government promotes. Government Performance Audit of the 1940s began to grow. Due to changes in public management and budgeting reforms in the government and the public, government performance audit in the 1960s and 1970s developed rapidly. Accounting can meet continuously and regularly do. But the audit, the situation is different because the opportunity cost of the audit function. To 
control costs, the auditors always the risk, internal control and respond to the risks created by the focus. After the bankruptcy of Enron (Enron), the auditors found that the internal control system that is very difficult to detect fraud conducted by auditors and management. The International Accounting Standards Board Audit and assurance, risk-taking 5 models include an indoor setting and stated that internal control is integrated. In fact, internal audit is a management consulting. Also, the internal auditor to conduct an internal control system that authenticates and accountability is a valuable resource for other controls. Identify and process control increases the internal control (free benevolent and confectionery, 1377). In the future, the audit approach is based on the Value Added. Mainstream development approach based on risk audits and audit-based controls, and the ultimate goal of this approach is the creation of added value for the ( $\mathrm{Li}, 2005)$. State audit as a tool to improve government decision-making and creating of added value to the organization. Monetary and non-monetary benefits of added value have been paid benefits including reduced operating costs and non-monetary benefits include increased efficiency and improve the representation of the state. Independent audit by the Comptroller and Auditor-based risk management, foreign, and the creation of added value to the community.

\section{Conclusion}

Due to the achievement of the value added pathways are different, but the ultimate goal of modern accounting and auditing organization that is the creation of added value, achieve. The development of accounting and auditing principles, integrate them and make collective control method (liu, 2004). Internal audit of the three objectives of prevention, immunization and value added done. Prevention is by vaccination and value added. Immunization performance and added value acquired outside of added value, the total domestic demand for immunization (wang, 2004). Internal auditor's council believes that collective control structure should be based on mutual respect between the board, executives, internal auditors and external auditors to be established (iia, 2002). Social control theory of the view that management should review and approve changes to the scientific decision-support (li, 2005). The ultimate goal of social control, to achieve the organization's goals is to increase shareholder wealth. According to the methods of management, accounting and audit control objectives are similar. Value management, accounting and auditing, and the main instrument of added value, the ultimate goal is the implementation of accounting and auditing (chen et al., 2012).

\section{Acknowledgement}

With all the efforts of Mr. Professor Mahmoud Larry plain Bayaz in preparing this article, I would appreciate the help.

\section{References}

[1] Chen LH(2002), Value Management: Proposal of Pan Accounting [J], Accounting Research, (In Chinese), pp. 53-56.

[2] Liu JY(2008), Developing Auditing Affairs in All Aspects under the Instruction of Sustainable Development [J], Auditing Research, (In Chinese), pp. 3-9.

[3] Chen LH (2003), Development of Management Auditing and Changes on Management system [J], Auditing Research. (In Chinese), pp.42-45.

[4] Li JH(2005), Auditing is a Governmental Tool [J], China-Today Forum, (In Chinese), pp.43-45.

[5] Liu QM(2006), A Study on Governmental Performance Auditing Based on Public Accountability Theory [D], Xiamen University, (In Chinese)

[6] Li WA(2005), Corporate Governance [M], (In Chinese), Higher Education Press, Beijing.

[7] Qu Q(2006), A Study on Internal Auditing Based on Accountability Theory [D], Xiamen University, (In Chinese).

[8] Xiao MY, and Y. Cao(2008), Removing Accountability: the Same Goal of Modern Financing, Accounting and Auditing [J], Friends of Accounting (In Chinese), pp. (8): 66-69.
[9] Watts R.L., and J.L. Zimmerman(1986), Positive Accounting Theo ry, Eng lewood Cliffs: Prentice Hall.

[10] Green B.P., \& J.H. Choi(1997), Assessing the Risk of Management Fraud Through Neural Network Technology, Auditing: A Journal of Prac tice and Theory, 16 (1), 14-28.

[11] Wang GY(2002), View of Ac counting Accountability and Audit ing Accountability [J], Journal of Financial Accountant, (In Chi-nese), pp. (2): 3-5.

[12] Wu ZX(2000), Accountability: the Soul of Modern Accounting and Auditing, Friend of Accountant.

[13] Yan DW(2004), Accounting Research on Value Chain: Review and Expectation [J], Accounting Research, (In Chinese), pp. 3-7.

[14] Zhang Z.L(2009) On the Construction and Application of Government Management Accounting [D], Xiamen University. (In Chi nese). 